\title{
AZ ÉRDEKHORDOZÓI ELMÉLET HATÉKONYSÁGNÖVELŐ SZEREPÉNEK VIZSGÁLATA
}

$A z$ angolszász országokban a részvényesek érdekeinek elsőbbségére épülő vállalatirányítási szemléletmód uralkodik. Jelenleg egyetlen olyan gondolati iskola létezik, amely képes bizonyos mélységű elméleti megalapozottsággal és széles körű ismertséggel rendelkező alternatívát felmutatni. Az érdekhordozói1 elmélet ugyanis az elmúlt húsz év alatt viszonylag kiforrottá, éretté vált. Azonban ez a megközelítés alapvetően nem a hatékony vállalati működést állítja a középpontba, hanem - a részvényesi elsôbbséget hangoztató megközelítéshez képest - magasabb erkölcsi normákat fogalmaz meg azokkal szemben, akikre a vállalat működése kihat. De az elmélet nem szakad el a vállalat hatékony működésének vizsgálatától. Sőt, egyes megközelítések még a részvényesek számára is nagyobb megtérülést ígérnek, annak ellenére, hogy itt a cél nem a részvényesek érdekeinek kiemelt kezelése. A jelen tanulmány tárgyát az érdekhordozói megközelítések bemutatása és hatékonyságalapú vizsgálata képezi. Végezetül pedig a hatékony vállalati működést középpontba állító érdekhordozói vállalatelmélet alapjainak lefektetésére kerül sor.

Az angolszász vállalatirányítási (corporate governance) rendszerben a nyilvános részvénytársaságok célja a részvényesi érték (shareholder value) maximalizálása. Ennek a szemléletmódnak a szerződéses vállalatelméletek ${ }^{2}$ biztosítanak megfelelő elméleti megalapozottságot. Elegendő a klasszikusok közül csupán két műre felhívni a figyelmet. Williamson részletesen (1985) felsorolja azokat az okokat, amelyből kifolyólag a részvényesek érdekét a többi vállalati szereplő érdeke elé kell helyezni. Jensen - Meckling (1976) pedig megbízó-ügynök viszonyként azonosítja a részvényesek és a menedzserek kapcsolatát, amiből már adódik az opportunizmusra hajlamos menedzsment feladata és erkölcsi kötelezettsége: a részvényesi érték maximalizálása.

Természetesen több olyan elméleti megközelítés is van, amely másképp látja a vállalatirányítás célját vagy a menedzsment viselkedési jellemzőit, de az érdekhordozói elmélet kivételével még nincsenek fejlettségük olyan szakaszában, hogy tényleges alternatívaként számba lehessen venni őket ${ }^{3}$. Az érdekhordozói elméletre viszont mind az elméleti, mind pedig a gyakorló szakemberek egyre nagyobb érdeklődéssel tekintenek (Jones - Wicks, 1999). Már 1995-ben a menedzsment szakirodalomban ezzel kapcsolatban több mint száz cikk és egy tucatnál is több könyv jelent meg (Donaldson - Preston, 1995). Ez a lendület még manapság sem tört meg.

Indulásként célszerű vázlatosan bemutatni, hogy mit is állít az érdekhordozói elmélet. Több meghatározó szerző (Donaldson, Preston, Wicks) a következő közös álláspontra helyezkedett (Consensus Statement on the Stakeholder Model of the Corporation ${ }^{4}$ ). A részvénytársaság célja az értékteremtés, az ennek folyamatában részt vevő egyének és csoportok alkotják az érdekhordozókat. Ők erőforrásokat biztosítanak a vállalat számára, és viselik a felmerülő költségeket. Közös jellemzőjük, hogy a vállalat működésével kapcsolatban kockázatot vállalnak, mert a tényleges hasznok és károk eltérhetnek a várakozásoktól. A hosszú távon fenntartható értékteremtés érdekében a vállalatnak folyamatosan mérlegelnie kell az érdekhordozói 
érdekek között, és hatékonyan, hozzájárulásuk függvényében kell megosztani közöttük a hasznokat és károkat.

Ennyiből már jól látható, hogy a pénzügyi közgazdaságtan területéről származó részvényesi elsőbbség szemléletmód kritikájának tekinthető az érdekhordozói elmélet (stakeholder theory).

Ezekkel a megközelítésekkel kapcsolatos viták középpontjában az a kérdés áll, hogy miért léteznek részvénytársaságok (Metcalfe, 1998). Csak azért, hogy a részvényeseknek nyereséget termeljenek, vagy ennél nagyobb szerepet kell betölteniük a társadalomban? A hagyományos szemlélet szerint a részvénytársaságnak a profittermelés az egyetlen feladata, míg az érdekhordozói elmélet arra az álláspontra helyezkedik, hogy a részvénytársaság fô funkciója az érdekhordozói érdekek összehangolása. A különböző nézőpontoknak megalapozottságot biztosít, hogy a részvénytársaság koncepciója jelentôsen eltér az egyes országokban. A kontinentális Európában és Japánban egy intézmény, önálló személyiséggel, karakterrel. Céljai az érdekhordozói csoportok széles körének érdekeit tükrözik, de egyik csoport érdekeivel sem egyezik meg teljes mértékben. Ezzel szemben áll az angolszász megközelítés, ahol a részvénytársaság inkább magán, mintsem közösségi intézmény.

Kochan - Rubinstein (2000) az amerikai részvénytársaságok jövőjével kapcsolatos társadalmi vita legfontosabb vizsgálandó kérdésének tekinti, hogy továbbra is a részvényesi érték maximalizálása lesz a részvénytársaság kizárólagos célja, vagy felelőssé kell tenni azt, számos további érdekhordozó céljainak eléréséért is. Ez utóbbi eset ugyanis lehetőséget teremt a létrehozott értéknek és a vállalt kockázatnak a vállalati szereplők közötti arányosabb elosztására.

A továbbiakban az érdekhordozói elmélet, mint pillanatnyilag egyetlen, kellően kiforrott alternatív vállalatirányítási koncepció sajátosságai kerülnek bemutatásra. A tanulmány célja annak az állításnak a vizsgálata, hogy a részvénytársaság az érdekhordozói megközelítés alkalmazásával nagyobb vállalati teljesítményre képes, mint a részvényesi elsőbbséget hirdető szemléletmóddal. Az érdekhordozói elméleten belül ugyanis van egy olyan irányzat, az ún. instrumentális érdekhordozói elmélet, amely szerint a részvényeseknek legalább akkora megtérülés biztosítható, mint a részvényesi elsőbbség követésével. Ez az állítás igen érdekes, ugyanis az érdekhordozói elmélet pontosan azt hangoztatja, hogy a többi vállalati szereplő érdekét (azaz díjazását is) nem rendeli a részvényesek érdeke (megtérülése) alá. Alapvetően két kérdésre keresem a választ. Mennyire támasztható alá az érdekhordozói elméletnek a vállalati hatékonysággal való szoros pozitív kapcsolata? A kapcsolat szorosabbá tétele érdekében az elméleten milyen módosításokat kellene végrehajtani?

\section{Az érdekhordozói megközelítés története}

Habár az érdekhordozó kifejezés csak az 1960-as években bukkant fel először, a benne tükröződő szemléletmód már a részvénytársaság mint vállalati forma kialakulásakor megjelent. Az USA-ban a XIX. századra tehető, amikor az első részvénytársaságok megjelentek. Létrehozásuk bizonyos társadalmi célok eléréséhez kötődött. A törvényhozásnak egy speciális törvényt kellett elfogadni minden egyes részvénytársaság létrejöttéhez. A részvénytársaság csak azokat a tevékenységeket végezhette, amelyet a rá vonatkozó törvényben számára előírtak. Jól látható, hogy nem a részvényesek, hanem a társadalom (érdekhordozók) érdekei álltak a középpontban (Millon, 1990). A század végére azonban a törvényhozás általános célú részvénytársaságok létrehozását is lehetővé tette, és ezek száma robbanásszerűen megnőtt. Céljuk a profitszerzés volt, nem pedig a társadalmi célok elérése. A növekvő tömegpiacokból származó előnyöket használták ki, és hatalmas tőkeszükségletük miatt a részvénytőke vált a legfontosabb (legszúkebb) erőforrássá (Kochan - Rubinstein, 2000; Prahalad, 1993; Roe, 1994; Smith - Dyer, 1996; Calomiris - Ramirez, 1996). Tehát az általános meggyőződéssel szemben a részvényesi érték maximalizálás a közgazdaságtannak nem egy olyan alapvető szabálya, amely a részvénytársaság létrejöttétől kezdve mindig is fennállt (Kochan - Rubinstein, 2000). A részvényesi megtérülés mint központi cél csak a XIX. század végén jelent meg először (Sundaram - Inkpen, 2004).

A XX. század húszas éveiben azonban ismét fordult a kocka. A tőzsde összeomlása és a nagy gazdasági recesszió erőteljes hatást gyakorolt a közgondolkodásra. Ekkor zajlott Dodd és Berle híres vitája a Harvard Law Review hasábjain azzal kapcsolatban, hogy kinek az érdekei szerint kell vezetni a részvénytársaságot.

Berle (1931) arra hívta fel a figyelmet, hogy a részvénytársaság menedzsmentjének a rendelkezésére álló hatalmat mindig a részvényesek érdekeinek megfelelően kell felhasználnia (Weiner, 1964). Úgy kell ezt a 
hatalmat szabályokkal korlátozni, hogy ne lehessen öncélúan (a részvényesek érdekeitől eltérően) felhasználni. Jogi értelemben a menedzserek szerepét a megbízott (trustee) szerepéhez hasonlította.

Rá egy évre, jelent meg Dodd (1932) válasza, aki még szélesebb megbízotti megközelítéssel állt elő. Nem fogadta el, hogy a részvénytársaság kizárólagos célja a részvényesek számára történő profitmaximalizálás. Arra a felismerésre jutott, hogy a társadalom elvárása az üzleti tevékenységgel szemben változik, növekszik annak a társadalommal szembeni kötelezettsége. Ez a részvénytársaság esetén azt jelenti, hogy annak a profittermelés mellett társadalmi szolgáltatás nyújtási feladata is van (Dodd, 1932:1148). Sőt, egyes esetekben a vállalati szereplők (munkavállalók, vevők) érdekeit akkor is figyelembe kell venni, ha ezzel a tulajdonosok jogai (érdekei) sérülnek (Dodd, 1932:1162).

Berle (1932) Dodd nézőpontjával nem értett egyet. Szerinte a részvényesek irányába fennáiló felelősség, kötelezettség csak akkor korlátozható, ha a társadalom szereplőivel szemben objektíven kikényszeríthető felelősség, kötelezettség fogalmazható meg. Ennek hiányában csak az érhetô el, hogy a menedzserek abszolút hatalomra tesznek szert, és nem lesznek felelősségre vonhatók. Viszont Berle még ebben az évben kiadott könyvében elismerte, hogy a tulajdon és a kontroll elválása következtében a részvénytársaságot nemcsak a részvényesek, mint passzív tulajdonosok, hanem a társadalom érdekei szerint kell vezetni (Berle - Means, 1932:311-313). A kettejük közötti különbség lényegében lecsökkent arra, hogy kell-e egy hatékony számonkérési mechanizmus a menedzserek felelősségre vonása érdekében. Dodd ugyanis nem tekintette előfeltételnek egy ilyen mechanizmus kialakítását (Weiner, 1964).

Az érdekhordozói megközelítések jellemzője, hogy a Dodd - Berle vita kapcsán csak a 30-as évek elején megjelent publikációkkal foglalkoznak. A későbbiekben azonban a szerzők álláspontja igen közel került egymáshoz.

Egy 1954-es cikkében Berle már nem ragaszkodott egy olyan mechanizmus kialakításához, amelyen keresztül a menedzsmentnek a társadalom számára nyújtott szolgáltatásai jól számon kérhetőek (Weiner, 1964). Sőt, el is ismerte, hogy a jogalkotás Dodd szemléletmódjával megegyező irányban fejlődött tovább. Tehát a XX. század első három évtizedét jellemző részvényesi érzület, az azt követő négy évtizedben a társadalmi szereplőket pártoló érzületbe csapott át (Sundaram - Inkpen, 2004).
Azonban érdemes kitérni arra is, hogy a későbbiekben Dodd hogyan pontosította álláspontját. Egy könyvrecenzióban (1942) felhívta a figyelmet arra, hogy a menedzserek megbízotti kötelezettsége más természetű a munkavállalókkal és a vevőkkel mint a részvényesekkel szemben. Tehát jogi szemszögből nem pontos a széles körben értelmezett megbízotti felfogás. A menedzsereknek a részvényesekkel szembeni jogi kötelezettsége az olyan profitmaximalizálás, ami nem sérti a társadalom érdekeit, valamint a meglévő jogszabályokat és szerződéseket. A menedzsmentnek nincsen ilyen jogi kötelezettsége az alkalmazottakkal szemben, azaz nem kell olyan tevékenységeket végeznie, ami a munkavállalók bérének növelését célozza ${ }^{5}$. Csak annyi a feladatuk ezekkel a vállalati szereplőkkel szemben, hogy bizonyos speciális igényeiknek eleget kell tenni, amit számukra a szerződések, az előírások és a törvények biztosítanak.

A 60-as évek első felében bukkant fel először az érdekhordozói kifejezés a Stanford Research Institute egyik anyagában (Freeman, 1984).

A 80-as évek elején két fontos dolog is történt. Ekkor jelent meg Freeman (1984) könyve, ami az érdekhordozói elmélet kialakulásának kezdetét jelentette. Ö a stratégiai menedzsment keretein belül használta az érdekhordozó kifejezést. A menedzserek döntéshozatalának minőségét akarta javítani olyan vállalatok esetén, amelyek gyors változásokkal jellemezhetô környezettel szembesülnek. A stakeholder elemzési keret lehetővé teszi a környezet szisztematikus figyelését, és proaktív módon történő menedzselését. 1984-es könyvét követve a stratégiai menedzsment és az üzleti etika területéről rengeteg ezzel foglalkozó publikáció látott napvilágot.

A másik változás a részvénytársaságok irányításával kapcsolatos gondolkodásmódhoz kapcsolódott. Ismét középpontba került a részvényesi elsőbbség, ami több okra volt visszavezethető (Lazonick - O'Sullivan, 2000).

- A 70-es években jelentősen csökkent az amerikai részvénytársaságok versenyképessége, aminek az oka az erős japán verseny és a túl nagyra nőtt konglomerátumok hatékonytalan működése volt.

- A topmenedzsereknek az 50-es évektől kezdve egyre nagyobb érdekük a részvények árfolyamának emelése, ugyanis a részvényopció díjazásuk jelentős részét képezi.

- A 70-es években a pénzügyi közgazdászok részéről központi szerepet kapott az a gondolat, hogy a

\section{VEZETÉSTUDOMÁNY}


nyilvános részvénytársaság esetén a menedzserek és a részvényesek érdekei elválnak, a menedzseri opportunizmus sérti a részvényesek érdekeit. Ekkor terjesztették ki a megbízó-ügynök elméletet a nyilvános részvénytársaságokra. Mivel a piaci mechanizmusok nem eléggé fegyelmezik meg a menedzsereket, kihangsúlyozták a vállalatfelvásárlások piacának kialakítása iránti szükségletet. A vállalati teljesítmény mértéke a vállalati részvényekre számolt megtérülés lett, és így került középpontba a részvényesi érték maximalizálása ${ }^{6}$.

A 80-as években - a részvényesi érték maximalizálás megerősödésével párhuzamosan - az érdekhordozói koncepció felbukkant a vállalati jogban is szorosan kapcsolódva a vállalatirányításhoz. Az USA 30 államában fogadtak el érdekhordozói törvényeket (constituency statutes), amelyek lehetővé tették az igazgatóknak, hogy a döntéshozatalban a részvényeseken kívül más vállalati szereplők érdekeit is figyelembe vehessék (Orts, 1992).

A 90-es évektől kezdve a részvényesi érték maximalizálást, mint kizárólagos célt erős kritikával illetik. Azzal vádolják ezt a szemléletmódot, hogy a részvényesek aránytalanul nagy részesedést kapnak a vállalat által kitermelt hozamból. Ez pedig a vállalati érdekhordozók, és különösképpen a munkavállalók hátrányára történik (Useem, 1996)7

\section{Az érdekhordozók azonosítása és a megközelítések tipologizálása}

Az előbbi fejezet alapján jól látható, hogy az érdekhordozói szemlélet lényegében együtt jelent meg a részvénytársaságok kialakulásával, és egyes időszakokban igen erőteljes hatást gyakorolt a vállalatirányításra. Azonban az érdekhordozó kifejezés csak a múlt század második felében jelent meg. A Stanford Research Institute (SRI) számára készült 1963-as kutatási feljegyzés említette először ezt a szót. Az érdekhordozókat olyan csoportokként definiálta (Freeman, 1984), amelyek támogatása nélkül a vállalat megszűnne. Itt az érdekhordozó kifejezés konkrétan a részvényesekre, a munkavállalókra, a vevőkre, a szállítókra, a hitelezőkre és a társadalomra vonatkozott. Az SRI feljegyzés arra hívta fel a figyelmet, hogy amíg a vállalati menedzserek nem értik meg a stakeholder csoportok szükségleteit és problémáit, addig nem tudnak olyan vállalati célokat megfogalmazni, amelyek az érdekhordozóktól megkapnák a vállalat fennmaradásához szükséges támogatást (Jennings, 1999). Nemcsak a tulajdonosokra, hanem azokra a vállalati szereplőkre is kiemelt figyelmet kell fordítani, akik viselkedésükkel jelentősen befolyásolni képesek a vállalat működési hatékonyságát (Barry, 2002; Sternberg 1997). Itt a vállalat alapvető célja nem változott, csak annak hatékonyabb kivitelezését akarták biztosítani.

Freeman - Reed (1983) szerint az SRI definíciója túl általános és túl kizáró, hogy képes legyen azoknak a külső csoportoknak az azonosítására, akik stratégiailag fontosak ${ }^{8}$. Ezért Freeman - Reed (1983) két alternatív definíciót is megfogalmazott:

„A széles értelemben vett érdekhordozók: Minden azonosítható csoport vagy egyén, aki képes hatást gyakorolni a szervezet céljainak teljesítésére, vagy akire hatással van a szervezet céljainak elérése".

„A szűk értelemben vett érdekhordozók: Minden azonosítható csoport vagy egyén, akitől a szervezet függ a folyamatos túlélése érdekében."

Ők a széles értelemben vett definíciót tartják meghatározónak. Freeman az 1984-es könyvében is ezt fogadja el. Látható, hogy ez jóval szélesebb megfogalmazás, mint amit az SRI használt. Freeman szerint a definíció által lefedett összes szereplő alapvető szerepet játszik a vállalat sikerében, és rendelkezik ,érdekkel" a modern részvénytársaságban. Az érdekhordozók széles körű értelmezésének következménye, hogy olyan csoportokat is magába foglal, amelyek nem igazán legitimek (mint például a terroristák). A definíció első fele stratégiai menedzsment szemszögből nézve egyértelmű. Azok az érdekhordozók, akik képesek (nemcsak gazdasági értelemben) a vállalat múködését befolyásolni. A definíció második felére vonatkozóan viszont Freeman (1984) igen érdekes érveléssel állt elő. Manapság már vannak olyan, a vállalatot befolyásolni képes érdekhordozók, akiknek erre eddig nem volt lehetőségük. A vállalat már korábban is (negatív) hatással volt rájuk, de ezzel egyáltalán nem foglalkozott. Azonban az utóbbi években módosult a vállalattal szembeni viszonyuk, erőpozíciójuk, amiben jelentős szerepet játszott a részvénytársaság korábbi viselkedése. Innen már nyilvánvaló, hogy a definíció második fele a hosszú távú hatékony múködést lehetővé tévő viselkedést biztosítja. Megjelenik a társadalmi felelősség, mint a hosszú távú hatékonyság eszköze.

Freeman korábban már bemutatott széles definíciójával szemben az elmúlt húsz évben számos, más meghatározás is született. A későbbiekben ennél szűkebb 
megfogalmazások kerültek előtérbe. Ezek inkább bizonyos prioritásokat fogalmaztak meg az érdekhordozók azonosításával kapcsolatban. Meghatározták, hogy milyen jellemzőkkel kell bírnia egy érdekcsoportnak, hogy a vállalattal szemben legitim követeléssel lépjen fel. A szűkebb definíciók (Mitchel et al., 1997) egyik ága azok a meghatározások, ahol az érdekhordozók szorosan kapcsolódnak a vállalat alapvető gazdasági érdekéhez. A szűkebb megközelítések másik ága pedig csak azokat a csoportokat tekinti érdekhordozóknak, amelyek a vállalattal szemben erkölcsi követeléssel rendelkeznek. Ez utóbbi ágra jellemző, hogy egy olyan normatív mag meghatározására törekedtek, amely valamilyen formájú legitimációt biztosít az érdekhordozók számára. Azonban fontos kihangsúlyozni, hogy az érdekhordozói definíciók igen változatosak. Ezeknek jó áttekintését adja Mitchel et al. (1997).

Két dolgot fontos kihangsúlyozni. Egyrészt a szerzők definíciói között olyan alapvető különbségek vannak, hogy nem igazán lehet egységes elméletről beszélni. Helytállóbb az a megfogalmazás, hogy rokon szemléletű megközelítések csoportjával állunk szemben. Másrészt pedig Freeman, a szélesebb értelmú definíciójával megnyitotta az elmélet „kapuit” az üzleti etikával foglalkozók előtt is. Ugyanis az érdekhordozó címszó alatt olyan szereplők érdekének figyelembevétele is kihangsúlyozható, akik most nem képesek a vállalat működését befolyásolni, és talán soha nem is lesznek rá képesek. Ennek a 90-es években erős elhajlás lett a következménye. Meghatározó szerzők az érdekhordozói definíciót úgy szúkítették le, hogy csak a legitim követelésekkel rendelkező vállalati szereplőket azonosították érdekhordozóként. Ezek a szerzők alkották az előbb említett szűk definíciók egyik ágát. Tehát nemcsak Freeman definícióját szűkítették le, hanem ezzel együtt lényegében az érdekhordozói megközelítést ki is emelték a stratégiai menedzsment területérôl és áthelyezték az üzleti etika területére.

Jó példa erre Donaldson - Preston (1995) szemléletmódja. „Az érdekhordozók azokon a tényleges és potenciális károkon és hasznokon keresztül azonosíthatók, amelyeket átélnek, vagy úgy látják, hogy át fognak élni a vállalat tevékenységének vagy tétlenségének következtében" (Donaldson - Preston, 1995:85). Arra az álláspontra helyezkedtek, hogy az érdekhordozók a részvénytársaságban legitim érdekkel rendelkező egyének vagy csoportok. Minden érdekhordozó érdekének belső értéke van, figyelembevétele nem attól függ, hogy mennyire képes a részvényesek érdekét, azaz a vállalat hagyományos pénzügyi céljait előmozdítani. Továbbá egyértelműen különválasztják az érdekhordozókat a befolyásolóktól. Egyes érdekhordozók képesek a vállalat működését befolyásolni, míg mások nem. De vannak olyan befolyásolók is, akik nem érdekhordozók (terrorista). Nekik ugyanis nem származik hasznuk abból, ha a vállalat sikeresen múködik.

Azonban ez a tendencia az utóbbi években megfordulni látszik, és ismét szélesebb körben értelmezik az érdekhordozókat.

Phillips (2003) különbséget tesz az érdekhordozók között. A normatív legitimációval rendelkező érdekhordozók irányába a vállalatnak morális kötelezettsége áll fenn, míg a derivatív legitimációval rendelkező érdekhordozók olyan hatalom birtokosai, amely képes a vállalat érdekét előmozdítani, illetve gátolni. A normatív érdekhordozók alkotják azt a csoportot, amelynek az érdekei szerint kell a vállalatot vezetni. A hatalommal bíró, de normatív legitimációval nem rendelkező vállalati szereplők érdeke csak olyan mértékben lesz figyelembe véve, ami a normatív érdekhordozók érdekét előmozdítja. Jó példa erre az, hogy egy vállalat menedzsmentjének a terroristák érdekeit is figyelembe kell vennie olyan mértékben, amennyire azt a munkavállalóinak és vevőinek az érdeke megkívánja.

Mitchell et al. (1997) szerint sem maradhatnak figyelmen kívül azok a piaci szereplők, akik tevékenységükkel képesek befolyásolni a vállalat eredményességét, működésének sikerességét. Phillips (2003) előbb idézett álláspontjához hasonlóan a stratégiai menedzsment szempontjából fontos érdekhordozókat ők is csak eszköznek tekintik a legitim érdekhordozók érdekeinek érvényesítése céljából.

Phillips et al. (2003:480) szerint ,az érdekhordozói elmélet a szervezeti menedzsmentnek és az etikának az elmélete". Az érdekhordozókkal kapcsolatban ők is arra az álláspontra helyezkednek, hogy egy részük normatív okokból kifolyólag jogosult az érdekhordozói státusra, ők képezik a legitim érdekhordozókat. A többivel pedig csak stratégiai okokból kifolyólag kell foglalkozni, mert hatalmukkal képesek a vállalat tevékenységének eredményességét befolyásolni.

Az utóbbi három megközelítés alapján jól látható, hogy az érdekhordozók köre ismét kibővült. De az elmélet magját továbbra is az etikai megfontolások képezik. Míg Freeman (1984) könyvében az etikus viselkedés csak eszköz volt, itt már céllá lépett elő. 
Az érdekhordozói elméletek tipologizálásával kapcsolatban a legnagyobb előrelépést Donaldson Preston (1995) megközelítése jelentette. A szerzőpáros a különböző megközelítéseket vizsgálva arra a következetésre jutott, hogy három eltérő célra használják fel azokat.

Egyesek azt kívánják érzékeltetni, hogy a vállalati gyakorlatban az érdekhordozói szemlélet érvényesül (leíró jelleg). Sokszor az érdekhordozói menedzsment gyakorlása és a hagyományos teljesítménymutatók alapján elért teljesítmény közötti pozitív kapcsolatot próbálják meg empirikusan, statisztikai adatok alapján megragadni. Tehát az érdekhordozói megközelítés gyakorlásával a részvényesek is legalább akkora megtérülést érnek el, mintha a részvénytársaságot a részvényesi elsőbbség elve alapján vezetnék (instrumentális jelleg). Sőt, az elmélettel olyan kérdésekre is választ adnak, hogy miért szükségesek a részvénytársaságok, milyen célt szolgálnak. Itt a vállalat vezetésére vonatkozó erkölcsi és filozófiai vezérelvek jelennek meg, hogyan is kellene a részvénytársaságot irányítani (normatív jelleg).

Ebből következik, hogy az érdekhordozói elmélet relevanciája, megalapozottsága három eltérő irányból vizsgálható (Donaldson - Preston, 1995): a leíró pontosságából, az instrumentális erejéből és a normatív érvényességéből. Donaldson - Preston szerint ezek az aspektusok egymásban helyezkednek el. Legkívül a leíró aspektus helyezkedik el, ami visszaadja a vállalati valóságot. Ezt erősíti az instrumentális réteg, amely ok-okozati kapcsolatot teremt az érdekhordozói viselkedés és a javuló vállalati teljesítménymutatók között. De a legbelső réteg a normatív, ugyanis mind a leíró, mind pedig az instrumentális aspektus normatív alapfeltevésen nyugszik. Ez pedig az, hogy minden vállalati érdekhordozó érdekének belső értéke van. Tehát a leíró és az instrumentális megközelítés önmagában nem teljes elmélet.

Ez a végkövetkeztetés azonban az érdekhordozói definíciójukból már egyértelműen következik. A szerzőpárost annak a szemléletmódnak a tipikus példájaként idéztem, akik csak a legitim követeléssel rendelkezőket tekintik érdekhordozónak. Így az instrumentális megközelítésnél olyan érdekhordozókkal is foglalkozni kell, akik hatékonysági alapon nem igazolhatók, mert nem képesek a vállalat működését befolyásolni.

Négy évvel később Jones - Wicks (1999) az elméleteket alapvetően két csoportra osztotta, ahol az egyikbe a leíró és az instrumentális, a másikba pedig a normatív megközelítések kerültek. Az érdekhordozók azonosításánál lényegében ők is a legitimációra építő, szűk körú, normatív megközelítést fogadták el. Arra a megállapításra jutottak, hogy önmagában az instrumentális és a normatív elméletek egyike sem teljes. Szükség van olyan konvergens érdekhordozói elméletre, ami mind normatív, mind pedig instrumentális elemeket tartalmaz. A két ágat össze kellene kapcsolni. $\mathrm{Az}$ érdekhordozók azonosításának módjából az az elvárás adódik az instrumentális elméletekkel szemben, hogy azokat csak morálisan igazolható célok érdekében szabad felhasználni, és ezek eléréséért csak morálisan megfelelő eszközökhöz lehet folyamodni. Azaz az instrumentális elméletnek szüksége van egy megfelelő morális magra. A normatív megközelítésekkel szemben pedig fontos követelmény a megvalósíthatóság. Az ezt gyakorló vállalat maradjon életképes, megfelelő profitot tudjon kitermelni. A normatív és az instrumentális megközelítések összekapcsolásával olyan konvergens érdekhordozói elméleteket kell létrehozni, amelyeknek morális szempontból megfelelő normatív magja van, és a gyakorlatban versenyelőnyhöz, vagy más megfogalmazásban nagyobb pénzügyi teljesítményhez is vezetnek.

Jones - Wicks (1999) több tekintetben is túllépett Donaldson - Preston (1995) megközelítésén. Felhívták a figyelmet az instrumentális elméletnek a normatív elmélettel való egyenrangúságára, és a konvergens érdekhordozói elmélettől azt is megkövetelték, hogy életképes legyen. Azonban Donaldson - Preston megközelítéséhez hasonlóan definiálták az érdekhordozókat, ami továbbra is lehetetlenné tette, hogy az instrumentális elméletet önmagában teljes elméletnek tekintsék.

Azonban nem mindenki ért egyet az előbbi állításokkal. Egyes szerzők azon a véleményen vannak, hogy az erkölcsös viselkedés hasznosságát nem kell instrumentálisan alátámasztani, hanem önmagában kell értékelni. Freeman (1999) pedig tudományelméleti, módszertani okokból nem fogadja el az előbbi tipologizálásokat.

\section{Az elmélet normatív magja és megvalósíthatósága}

$\mathrm{Az}$ érdekhordozói elmélet alternatív normatív magot fogalmaz meg a részvénytársaságok számára. Ennek relevanciáját az adja, hogy a részvényesi elsőséget alátámasztó normatív mag támadható. 
A részvényesi elmélet szerint (Hasnas, 1998; Phillips et al., 2003) a részvényesek a menedzsmentre bízzák befektetésüket, hogy azok, mint ügynökök a részvényesek érdekeinek megfelelően használják fel, azaz a részvényesi érték maximalizálására törekedjenek. A menedzsmentnek nincsen társadalmi felelőssége, csak a törvényeket és az általános etikai elveket kell betartania (Friedman, 1970). Ha ennek ellenére mégis teljesít társadalmi célokat, akkor nem a részvényesek érdekével összhangban cselekszik, ami erkölcstelen viselkedés.

Ezzel ellentétben számos jogtudós azon az állásponton van, hogy az igazgatóság és a menedzsment nem a részvényesek, hanem a részvénytársaság ügynöke (Clark, 1985; Wallman, 1999). Boatright (1994) pedig arra hívta fel a figyelmet, hogy a menedzsment és a részvényesek között fennálló viszonyra számos ok miatt nem illeszkedik a megbízó-ügynök megközelítés 9 .

A normatív érdekhordozói elmélet szerint a vállalat nagyobb felelősséggel tartozik érdekhordozói irányába, mint ami a részvényesi érték maximalizálás koncepcióból következik (Hendry, 2001). Azt hangsúlyozza, hogy a menedzsmentnek a részvénytársaságot az összes érdekhordozó érdekével összhangban kellene vezetnie, függetlenül attól, hogyan hat ez a vállalat pénzügyi teljesítményére (Hasnas, 1998). Itt a cél nem a részvényesek megtérülésének maximalizálása, hanem a részvénytársaságnak az érdekhordozók hasznára történő menedzselése. Ez pedig az eltérő és egymásnak részben ellentmondó érdekek megfelelő figyelembevételén és összehangolásán keresztül történik úgy, hogy az érdekhordozók valamilyen formában részt vesznek az őket érintő döntések meghozatalában. A menedzsment és az igazgatók bizalmi kötelezettsége nemcsak a részvényesekkel, hanem az érdekhordozókkal és a részvénytársasággal, mint entitással szemben is fennáll (Goodpaster, 1991; Moore, 1999). Ez olyan döntésekhez is vezethet, amelyek egyes érdekhordozók érdekeinek előmozdítása érdekében a részvényesek érdekének bizonyos mértékű korlátozásával járnak együtt. Ebben a megközelítésben az üzleti tevékenységnek van társadalmi felelőssége.

Azonban az érdekhordozói elmélet alapvető vonása, hogy a megközelítés normatív magját a szerzők különböző etikai elvek mentén próbálják meghatározni. Mivel ez a normatív mag alapvető fontosságú az elmélet szemszögéből, ezért az érdekhordozói megközelítéshez jobban illeszkedik az elméletek osztálya besorolás. A különböző megközelítések jól láthatóak az 1. táblázatban, ami nélkülözi a teljes körúséget (Phillips et al., 2003).

1. táblázat

Az érdekhordozói elmélet normatív magjai

\begin{tabular}{|l|l|}
\hline Szerző & Normatív mag \\
\hline $\begin{array}{l}\text { Argandona (1998) } \\
\text { Burton - Dunn (1996) }\end{array}$ & közjószág \\
\hline Wicks - Gilbert - Freeman (1994) & feminista etika \\
\hline Clarkson (1994) & kockázat \\
\hline Donaldson-Dunfee (1999) & $\begin{array}{l}\text { integratív társadalmi szerző } \\
\text { dések elmélete }\end{array}$ \\
\hline Donaldson-Preston (1995) & tulajdonjogok \\
\hline Evan-Freeman (1993) & kantianizmus \\
\hline Freeman (1994) & fair szerződések doktrínája \\
\hline Phillips (1997, 2003) & érdekhordozói fairség elve \\
\hline
\end{tabular}

Phillips et al. (2003:481)

Ez még nem is lenne probléma, ha mindegyik normatív mag olyan jól kimunkált lenne, hogy viszonylag kevés támadási felületet nyújtana. Azonban még az érdekhordozói elmélet szellemében alkotó szerzők is erősen megosztottak abban, hogy pontosan mi is az érdekhordozói megközelítés morális alapja (Jones Wicks, 1999; Hendry, 2001). Kívülről pedig igen heves támadások érik ezeket a normatív állásfoglalásokat.

A táblázatban felsorolt normatív magokkal összhangban lévő vállalatirányítási koncepció az ún. pluralista megközelítés (DTI Company Law Review Strategic Framework) ${ }^{10}$. Itt a vállalatokat társadalmi intézménynek tekintik, és mélyebb tartalmat adnak a társadalmi jóléthez történő vállalati hozzájárulásnak. A részvényeseken kívül más csoportoknak is van legitim érdekük a részvénytársaságban és követelésük vele szemben. Elismerik, hogy a különböző érdekhordozói csoportok érdekei (a részvényeseket is beleértve) nem mindig esnek egybe rövid távon, sőt lehet, hogy még hosszú távon sem. A pluralista felfogás szerint a társadalmi jólét olyan vállalati jogrendszerrel érhetô el legjobban, ami lehetővé teszi a szélesebb részvételt a vállalati döntéshozatalban így biztosítva, hogy minden érdekhordozó képviselve legyen.

Azonban erôs kritika éri a pluralista szemléletű vállalatirányítási megközelítést, több ponton is kétségbe vonva annak megvalósíthatóságát.

- Az érdekhordozói elmélet nem teszi lehetővé, hogy a szervezeteknek önálló céljuk legyen, mert minde- 
gyiknek a különböző érdekeket kell egyensúlyba hoznia (Sternberg, 1997).

- A megközelítés nem határozza meg egyértelműen, hogy kik is az érdekhordozók. Ez jól látható a korábban idézett definíciók alapján.

- Az elmélet azt sem határozza meg, hogy az egyes érdekhordozók milyen figyelembe veendő hasznosságokkal rendelkeznek, és hogyan kell súlyozni a különböző szereplők sokszor egymással ellentétes hasznosságai között (Sternberg, 1997).

- Ha a menedzserek nemcsak a részvényesek felé, hanem minden érdekhordozó irányába elszámolási kötelezettséggel tartoznak, akkor jelentősen megnő a mozgásterük önérdekük érvényesítésére az egyes csoportok egymás ellen való kijátszásával.

- Az érdekhordozói elmélet nem képes megfelelő célfüggvényt meghatározni, amely alapján a szervezet, azaz a menedzsment teljesítménye értékelhetô (Jensen, 2001). Ugyanis matematikailag belátható, hogy nem lehetséges egyszerre egynél több dimenziót maximalizálni ${ }^{11}$. Abban az esetben, ha egynél több cél maximalizálásával bízzuk meg a menedzsert, akkor igazából nem tűzünk ki elé megfelelően értékelhető célkritériumot, és így nem tud ésszerű döntéseket hozni.

- Az érdekhordozói elmélet a tulajdonosok ,diktátorságára" épülő üzleti rendszer múködését megpróbálja úgy átalakítani, hogy az az egyszerre számos érdek figyelembevételére képes politikai rendszerhez hasonlóan működjön (Barry, 2002). Viszont ha bevonjuk az érdekhordozókat a vállalati döntéshozatalba, akkor az Arrow (1963) által bemutatott problémába ütközhetünk. A csoportos döntéshozatal már igen egyszerű feltételek megfogalmazása esetén sem lesz olyan racionális, mint az egyéni döntéshozatal. Ráadásul a politikai élet egyéb kedvezőtlen vonásai (pl. egyes érdekcsoportok nyomása) is megjelennek a yállalati döntéshozatal szintjén.

A bírálatok hatására megjelent egy olyan álláspont is, hogy az érdekhordozói elmélet széles körű elfogadottságának elnyerése érdekében be kellene mutatni, hogy gazdaságilag sikeresebb működést tesz lehetővé, mint a részvényesi elsőbbségre épülő megközelítés. Úgy képes a részvénytársaság (társadalmi) teljesítményét emelni, hogy ez nem jár a részvényesi érték csökkenésével (Stoney - Winstanley, 2001). Ez más megfogalmazásban úgy hangzik, hogy az érdekhordozói elméletnek fair megtérülést kellene biztosítania a részvényesek számára (Jones - Wicks, 1999; Phillips et al, 2003).
Erre az instrumentális megközelítések tesznek kísérletet. Freeman (1999) szerint ezek a megközelítések a legígéretesebb jelöltek az érdekhordozói elméletfejlesztés számára, és saját bevallása szerint a nagy sikerű könyvében (1984) felvázolt megközelítése is instrumentális szemléletű volt. Egy olyan kutatási fórum is létrejött, ami az „Érdekhordozók, Társadalmi Felelősség és Teljesítmény" címet viselte. Itt a vizsgálat tárgya a vállalat etikus viselkedése és a különböző kategóriákban felmutatott teljesítménye közötti kapcsolat volt (Harrison - Freeman, 1999).

\section{Instrumentális megközelítések és a vállalatirányítási ajánlás}

Freeman et al. (2004) szerint az érdekhordozók elkötelezettsége érdekhordozói elmélettel jobban megteremthető, ugyanis az több erőforrást és nagyobb lehetőséget biztosít a menedzserek számára. Itt nemcsak a nagyobb pénzügyi juttatásról van szó. A menedzsereknek az érdekhordozókkal való kapcsolatából nyilvánvalóvá válik, hogy igen fontosnak tartják őket, és igyekeznek igényeiknek a jövőben is minél nagyobb mértékben megfelelni. Berman et al. (1999) pedig vizsgálataik alapján arra a következtetésre jutottak, hogy a menedzsment csak hatékonysági okokból használja az érdekhordozói elméletet. Csak azért, és csak olyan mértékben foglalkozik vele, amennyire az előmozdítja a vállalat pénzügyi teljesítményét. Tehát alapvetően nem morális okokból bánik „pozitív módon" az érdekhordozókkal. A továbbiakban ezért az instrumentális érdekhordozói elméletek felé fordul a figyelmem.

$\mathrm{Az}$ instrumentális érdekhordozói elméletek függő elméletek (Donaldson - Preston, 1995; Jones - Wicks, 1999). Ezek szerint bizonyos eredményeket elérhetünk, ha meghatározott módon viselkedünk. $\mathrm{Az}$ ilyen megközelítések állításai a vállalat eredményesebb működését ígérik, ami a hagyományos pénzügyi teljesítménymutatók értékeiben is jelentkezik. Ezeknek a pénzügyi teljesítménymutatóknak a javulása a részvényesek befektetéseinek nagyobb megtérülését jelenti.

Azonban ezek a megközelítések még nem igazán megalapozottak. Számos empirikus igazolási kísérlet eredményeinek áttekintése után több szerző is a következő megállapításra jutott: nincsen egyértelmű bizonyíték arra, hogy az érdekhordozói elmélet gyakorlásával a részvényesek is nagyobb hozamot rea- 
lizálnak (Donaldson - Preston, 1995; Jones - Wicks, 1999; Stoney - Winstanley, 2001; Sundaram - Inkpen, 2004).

\begin{abstract}
Ebben szerepe van annak is, hogy nem lehet olyan könynyen a vállalat érdekhordozói szemléletét beazonosítani. Nem olyan egyértelmû meghatározni, milyen vállalati jellemzők megléte esetén beszélhetünk érdekhordozói szemléletű vállalatirányításról. Azt sem olyan egyértelmú eldönteni, hogy egy részvénytársaságnál az érdekhordózói szemléletű vállalatirányítás teszi lehetővé a vállalat hatékony működését és nem pedig fordítva van ez.
\end{abstract}

Az instrumentális érdekhordozói elméletek igazolására további lehetőséget jelent, ha felsőbbrendűségüket olyan analitikus érvekkel sikerül alátámasztani, amelyek a hatékony vállalati múködéshez kapcsolódnak (Donaldson - Preston, 1995). Három alapvető megközelítés született ebben a szemléletmódban. A továbbiakban ezek tömör bemutatására és bírálatára kerül sor.

Hill - Jones szerzőpáros (1992) a vállalat, mint szerződések nexusa vállalatelméletek alapján a vállalatot explicit és implicit szerződések halmazának tekinti, ahol a nexus közepén a menedzserek helyezkednek el. Itt is megjelenik a megbízó-ügynök viszony, de ezt nemcsak a részvényesek és a menedzsment, hanem az összes érdekhordozó és a menedzsment között értelmezik. Az érdekhordozókat úgy definiálták, hogy legitim követelésük van a vállalattal szemben, ami a csere kapcsolatokból adódik. Kritikus erőforrásokat biztosítanak a vállalatnak, és cserébe azt várják, hogy az ő érdekeik is figyelembe legyenek véve. A hatékonyság szempontjából itt is a legfontosabb feladat, hogyan lehet a menedzserek - érdekhordozók szempontjából káros - opportunizmusának érvényesülését korlátozni. Itt a hagyományos ügynökköltség helyett a szerződési költség lett bevezetve, ami az összes szerződés ügynökköltségét magában foglalja ${ }^{12}$. Felhívták a figyelmet arra, hogy a menedzsment opportunizmusából származó veszteségeket nemcsak egy (menedzserrészvényes), hanem az összes dimenzióban egyszerre kell minimalizálni. Így érhető el a legnagyobb hatékonyság. Azonban az elmélet a korábbi megbízó-ügynök megközelítések hátrányai mellett további gyenge pontokkal jellemezhető, ami az érdekhordozói jellemzőkből ered.

- A megbízó-ügynök viszonynak az összes érdekhordozóra való kiterjesztése egyáltalán nincsen összhangban a nyilvános részvénytársaságokra vonatkozó amerikai társasági joggal.
- A szerzők abból indulnak ki, hogy a piacok nincsenek egyensúlyban, ezért az érdekhordozókat nem a végzett tevékenység piaci árával kell díjazni. Azonban az általuk alternatívaként használt „fairség" kategória szubjektív. Ha két vállalatnál ugyanazt a tevékenységet különböző díjazásért végzik, és mindkét tevékenységet végző elégedett a díjazásával, akkor egyértelműen a hatékonytalanság jele a drágábban dolgozó bértöbblete. Ez a hatékonytalanság azonban itt nem létezik.

- A szerződéses vállalatelméletekből importálva a szerzók még az érdekhordozók opportunizmusra való hajlamát is feltételezik, amiről részletesen ugyan nem beszélnek. Így egyes érdekhordozók mindent meg fognak tenni a számukra „legfairebb” díjazásért, függetlenül attól, hogy megérdemlik-e vagy sem. Tehát itt egy erős járadékvadászat (rent seeking) fog kialakulni, ami hatékonysági veszteséggel jár.

- Utalnak arra, hogy a nagyobb mértékű vállalatspecifikus befektetést végzők érdeke fontosabb. Viszont nem jelenik meg, hogyan kell az ő érdekeiket a többiekéhez képest kiemeltebben kezelni.

Freeman és Evan Williamson megközelítéséből indulnak ki, de nem tartják elfogadhatónak, hogy a vállalatot csak bilaterális szerződések halmazaként értelmezzék (Freeman - Evan, 1990; Freeman, 2001). Így ugyanis elsiklik a figyelem afelett, hogy az egyes bilaterális szerződések hatással vannak más vállalati érdekhordozókra is. Ezek az externáliák teljesen figyelmen kívül maradnak Williamsonnál (1985), és kedvezőtlen kihatásaik hatékonysági veszteséget okoznak. Mivel az érdekhordozók eszközspecifikus befektetései a többiekre is hatással vannak, fontos feladat az érdekhordozók ebből származó érdekellentéteinek feloldása. A vállalat szerződéseit át kell alakítani „fair” szerződésekké. A koncepció lényege az, hogy a meglévő érdekeink figyelmen kívül hagyásával kötjük meg a szerződést, mert így lehet biztosítani, hogy minden érintett fél számára „fair” szerződés jön létre. Bármelyik fél szerepe jutna nekünk, az számunkra megfelelő lenne ${ }^{13}$. Ebből kifolyólag a vállalat nem más, mint multilaterális szerződések halmaza. A menedzserek feladata pedig a szerződések igazgatása a fellépő érdekellentétek megfelelő kezelésével. Arra is felhívják a figyelmet, hogy a szúkebb értelemben vett érdekhordozók és a vállalat viszonya reciprocitással jellemezhető ${ }^{14}$. Mindkét fél tud egymásnak jó esetben hasznot, de rossz esetben jelentős kárt is okozni. Ezért nagyon fontos feladat a megfelelő színvonalú kapcso- 
latok kialakítása. Azonban ennél a megközelítésnél is több problémába ütközünk.

- Williamson (1985) megközelítésének egyik előfeltevése az egyén opportunisztikus viselkedésének eshetősége, ezért ebben a modellben nem elvárható, a lehetséges „fair” szerződések kimunkálása.

- Az egyének korlátozott racionalitása (Williamson másik előfeltevése) nem igazán teszi lehetővé annak pontos meghatározását, hogy egy adott szerződés kiket érint, és mekkora hatást gyakorol rájuk.

- Az érdekhordozók tapasztalatai, képességei, kockázatvállalási hajlama, alternatív lehetőségei jelentősen eltérnek egymástól. Ezért a menedzser nem képes a többi vállalati szereplő fejébe látni, csak a saját megítélése alapján cselekszik, hogy mik lehetnek a „fair” feltételek. Tehát a létrehozott „fair” szerződés csak a menedzser képzeletében lesz „fair”.

- Ráadásul a különböző menedzserek különbözőképpen láthatják a „fair” szerződés alapján járó díjazást. Ha mindegyik „fair” a befektetést végző félnek, akkor itt is eltérő hatékonysággal állunk szemben attól függően, hogy ki a vállalati vezető. Erről a hatékonytalanságról nem esik szó.

A vállalatot Jones (1995) is szerződések nexusának tekinti. A topmenedzsment középen helyezkedik el, ő áll az összes érdekhordozóval szerződéses viszonyban. Ők az alapján azonosíthatóak, hogy képesek befolyásolni a vállalat működését, és/vagy érdekük a vállalat jó teljesítménye. A szerző a vállalat, mint szerződések nexusa elméleteknek (Alchian - Demsetz, 1972; Jensen - Meckling, 1976) és a tranzakciós költségek elméletének (Williamson, 1975, 1985) vizsgálata alapján arra a következtetésre jut, hogy mindegyik megközelítés legfontosabb problémának a vállalati szereplők opportunizmusra való hajlamát tekinti. Ebből következően a fö feladat az opportunizmus optimális szintre történő leszorítása, ami a lehető legkevesebb költséget, veszteséget okozza a vállalatnak ${ }^{15}$. A minél hatékonyabb szerződések létrehozása így kompetitív előnyt jelent a vállalat számára. A kompetitív előny azonban úgy is elérhető, ha a szerződő felek nem opportunistán, hanem kölcsönösen kooperatív módon viselkednek, mert így kisebbek lesznek a szerződésekkel járó költségek. Ez pedig Jones szerint megfelelő vállalati etikával biztosítható. Sőt, az érdekhordozóikkal szemben megfelelő erkölcsöt és etikát felmutató vállalatok számára sok olyan szerződéskötési lehetőség is megnyílik, ami az opportunista vállalatok számára nem elérhető, mert azok megbízhatóságot és kooperációt követelnek meg. Tehát az érdekhordozói megközelítés bevonásával a korábbi vállalatelméletek nagyobb vállalati hatékonyságot eredményezhetnek. Az alapvető probléma itt is - az előző elméletekhez hasonlóan - a költség-haszon összevetéséből ered, amire az elmélet már nem ad választ.

- A fő kérdés az, mely érdekhordozók felé miben és milyen mértékben nyilvánuljon meg az etika. A vállalatnak azt kell mérlegelnie, hogy adott költségekkel járó etika az opportunizmus mérséklésével mekkora költségcsökkenést és más haszonnövekedést képes biztosítani. Mi az a minimális feltétel, amit az egyes érdekcsoportoknál biztosítani kell, hogy a velük szemben biztosított magatartás etikusnak számítson. Erre azonban az elmélet már nem ad választ. Tehát az etika is olyan szubjektív fogalom, mint a „fair” szó. Szoros kapcsolata van a hatékonysággal, de önmagában még nem elegendő az optimális hatékonyság biztosításához, sokkal pontosabb, objektívebb mérce kellene.

Mindhárom elmélet felismeri, hogy az érdekhordozók érdekeinek nagyobb figyelembevétele a vállalati hatékonyság növekedését eredményezheti. Viszont nem képesek az optimális hatékonyságot biztosítani, mert szubjektivitásukból adódóan nem tudják pontosan megmondani, hogy az egyes szereplőknek minimum mit kell nyújtaniuk (amivel már a tőlük elvárt teljesítmény biztosítható), és hogyan kell őket egymáshoz képest eltérően kezelni a vállalat hatékonyságában betöltött szerepüknek megfelelően. Ez a korlátozottságuk pedig a vállalat érdekhordozóinak azonosításából fakad. Mindegyik szemléletmódra jellemző, hogy az érdekhordozók definiálásánál nemcsak azokkal foglalkoznak, akik a vállalat teljesítményét befolyásolni képesek, hanem azokkal is, akik csak erkölcsi okokból kifolyólag sorolhatók ide. Ha egyes vállalati szereplőket csupán normatív okokból kifolyólag tekintünk érdekhordozónak, akkor ezzel a következő normatív állítást is elfogadjuk. Az érdekhordozók érdekét önmagáért kell figyelembe venni függetlenül attól, hogy képes-e elősegíteni a vállalat hagyományos pénzügyi mutatóinak javulását. Ez pedig alapvetően nem hatékonyságközpontú szemléletmód.

\section{Új távlatok az instrumentális érdekhordozói elméletek számára}

Első ránézésre úgy tűnik, zsákutcába jutottunk. Habár a részvényesi elsőbbség vállalatirányítási megközelítés normatív alapja támadható, az érdekhordozói elmélet által javasolt alternatív normatív magok 
nem hoztak áttörést. Az érdekhordozói elmélettel foglalkozó szerzők nem képesek közös álláspontot kialakítani, hogy mi legyen az elmélet normatív magja. Ezért inkább csak lehetséges normatív magok csoportjáról beszélhetünk. Ezek mindegyike heves támadásnak van kitéve. Továbbá az érdekhordozói szemléletmódot azért is bírálják, mert megvalósítása közben olyan problémák merülnek fel, amire az elmélet nem kínál megfelelően kiforrott válaszokat. Az érdekhordozói elmélet és a vállalati hatékonyság szoros pozitív kapcsolatát az ún. instrumentális érdekhordozói elméletek próbálják alátámasztani. Eddig azonban még nem sikerült olyan egyértelmű empirikus bizonyítékot szolgáltatniuk, miszerint az érdekhordozói elmélet gyakorlásával a részvénytársaságnak nemcsak a társadalmi teljesítménye, hanem a hagyományos pénzügyi teljesítménye is javulni fog. Az instrumentális megközelítések alátámasztására további lehetőségnek tűnt olyan alternatív, érdekhordozói szemléletû vállalatelméleti megközelítések kidolgozása, amelyek analitikus érvekkel bizonyítják, hogy az érdekhordozói szemléletben irányított vállalatok hatékonyabban működnek. De az ilyen megközelítéseknél nemcsak hatékonysági, hanem normatív érveket is felhasználtak, így a következtetéseik nem meggyőzőek.

Azonban egy ezzel ellentétes tendencia is megfigyelhető. Az ún. enyhített részvényesi érték megközelítés (enlightened shareholder value) erősen épít az érdekhordozói szemléletre (DTI Company Law Review Strategic Framework) ${ }^{17}$. Azt állítja, hogy a részvényeseknek nyújtandó maximális érték célkitűzés az érdekhordozókkal szembeni hosszú távú kapcsolatok kialakításával és folyamatos fejlesztésével érhető el. Bár Jensen (2001) elméletét az enyhített érdekhordozói elmélet (enlightened stakeholder theory) névvel illeti, ennek ellenére itt is az előbbi szemléletmód tükröződik. A szerző felhívja a figyelmet arra, hogy a hosszú távú vállalati értékmaximalizálás nem mond semmit arról, hogyan lehet ezt biztosítani. A vállalatnak megfelelő víziót és erre épülő stratégiát kell kialakítania, valamint el kell érnie alkałmazottai magas szintű elkötelezettségét és motiváltságát. Ebben segít az érdekhordozói elmélet.

$\mathrm{Az}$ érdekhordozói elmélet eltérő megítélésének megértése érdekében az érdekhordozók definiálásához kell visszanyúlni. Felhívtam a figyelmet arra, hogyan változott meg a szó jelentése az elmúlt húsz év folyamán. Jól látható, hogy az SRI a vállalat alapvető gazdasági érdeke alapján definiálta az érdekhordozókat. A 90-es évek folyamán viszont megerősödött az a szem- léletmód, ami a legitim érdekkel rendelkező vállalati szereplőket tekintette érdekhordozóknak. Fontos észrevenni, hogy ezekben a megfogalmazásokban az elhanyagolható befolyásoló képességgel rendelkező érdekhordozók nem hatékonysági, hanem etikai megfontolások miatt vannak jelen. Ez már jóval nagyobb normatív elvárás, mint amit annak idején Dodd megfogalmazott. Egy később írt könyvrecenzióban ugyanis csak azt várta el a menedzsmenttől, hogy a profitmaximalizálás közben viselkedésük teljes mértékben összhangban legyen a szerződésekkel, a törvényekkel, és az általános etikai elvekkel. Kezdetben Freeman (1984) is csak a vállalat hagyományos céljának előmozdításáért vette figyelembe az etikai megfontolásokat. Azonban a legitimációt hangoztató definícióra épültek a normatív megközelítések mellett az instrumentális megközelítések is. Ez már megmagyarázza azt, hogy miért nem lehet az érdekhordozói elmélet életképességét és hatékonyságnövelő szerepét egyértelmúen alátámasztani. Ezzel szemben az enyhített részvényesi érték megközelítés és az enyhített érdekhordozói elmélet inkább az SRI definíciója alapján értelmezett érdekhordozókra épít.

Azonban van lehetőség az instrumentális elméletek továbbfejlesztésére jobb vállalatelméleti megalapozottság kialakításával, és az ebből adódó következtetések felhasználásával. Egy olyan érdekhordozói vállalatelméletet célszerű létrehozni, ami analitikus szempontból jól védhető, azaz bizonyítja életképességét. Az ebből adódó következtetések alapján pedig az instrumentális elméletek pontosabban megfogalmazhatók. Ennek érdekében viszont úgy kell definiálni az érdekhordozókat, hogy azok azonosításánál ne legyenek jelen az etikai, csak a gazdasági szempontok. Így az instrumentális és a normatív megközelítés teljesen elválik egymástól, és az instrumentális elmélet nem foglal magában az általános erkölcsi elvek betartásánál nagyobb morális kötelezettséget az érdekhordozói irányba.

Fontos kihangsúlyozni, hogy a hatékony vállalati működés útjában álló legfontosabb gazdasági problémának nem a menedzseri önérdek korlátozását fogom tekinteni annak ellenére, hogy a szerződéses vállalatelméleteknél ez a központi feladat, és ebbe az irányba mozdult el Hill - Jones (1992) is a megbízóügynök viszony importálásával. Ráadásul Phillips et al. (2003) szerint is ilyen kutatásokat kellene végezni az érdekhordozói megközelítés irányából.

$\mathrm{Az}$ alternatív szemléletmód kialakítása előtt érdemes áttekinteni az érdekeltség, az angol „,stakeholding" kifejezés jelentéseit. Sternberg (1999) szerint a

\section{VEZETÉSTUDOMÁNY}


szót három értelemben szokták használni. A „stakeholding" egyik jelentése arra utal, hogy a világ komplex, azaz viszonylag egyszerű eredmények elérése érdekében is számos tényezőt kell figyelembe venni. A szónak ebben a jelentésében a stratégiai menedzsment szemléletmódja tükröződik. A ,stakeholding” másik jelentése a ,jogosultsághoz" kapcsolódik, azaz az érdekhordozók érdekeit nemcsak figyelembe kell venni, hanem irányukba felelősségvállalást és elszámoltathatóságot is biztosítani kell. Ez a jelentés pedig az üzleti etika szellemiségét tükrözi. Végezetül a kifejezést a motivációval kapcsolatban is szokták használni, mivel az emberek nagyobb érdeklődést mutatnak bizonyos tevékenységek irányába, ha azok eredményében érdekeltek. A továbbiakban az instrumentális elméletek vállalatelméleti megalapozottságánál a szónak a motivációhoz kapcsolódó jelentéstartalmára építek.

Freeman és Evan korábban idézett két cikke alapján egy igen érdekes felismerésre lehet jutni. Felsejlik bennük egy alternatív hatékonysági koncepció. A szerzők amellett érvelnek, hogy a részvényeseken kívül más vállalati szereplő is befolyásolja, vagy pontosabban szólva, alapvetően meghatározza a vállalat sikerességét. Ezt elfogadva az érdekhordozókat az erőforrás-függőség megközelítés (resource dependence theory) irányából érdemes vizsgálni (Pfeffer Salancik, 1978). Itt az a központi gondolat, hogy a vállalat nem önellátó. Szüksége van környezetéből bizonyos inputokra, így függővé válik azok biztosítóitól. A két szemléletmódot összekapcsolva adódik, hogy az érdekhordozók olyan erőforrásokat birtokolnak, amelyekkel képesek a vállalati döntéseket befolyásolni. Sôt, erőforrásaikért cserébe el is várnak bizonyos tevékenységeket a vállalattól. Ebbe az irányba mozdult el többek között Berman et al. (1999) és Frooman (1999) is.

Az első lépés az érdekhordozóknak a vállalat erőforrás-függőségének szemléletmódjából történő definiálása. Érdemes visszatekinteni az SRI (1963) megközelítésére, mennyire összhangban van ezzel a szemléletmóddal. Az érdekhordozók azok, akik támogatása nélkül a vállalat megszűnne. Habár az érdekhordozók azonosításának uralkodó szemléletmódja megváltozott, de láthattuk, hogy Freeman - Reed (1983) és a későbbiekben mások is alkottak ilyen, a vállalat alapvető gazdasági érdekére összpontosító definíciókat. Az érdekhordozók azonosítására azonban az SRI megfogalmazása túl általános.
A továbblépés érdekében alaposabban meg kell vizsgálni a vállalat számára erőforrást biztosítókat. Ők alapvetően két csoportba sorolhatók. Egy részük olyan standard erőforrásokat kínál, amelyeknek van piaca, tehát a piaci árért cserébe a vállalat bármikor képes azokat beszerezni. Az erőforrások biztosítói is könynyen, nagyobb veszteség felmerülése nélkül találnak erőforrásuknak alternatív felhasználási lehetőséget. Tehát itt egyik félnek sem elemi érdeke a kapcsolat további fenntartása. A vállalat által felhasznált erőforrások másik része viszont a vállalat igényeinek megfelelően erősen specializált, így a vállalat azokat nem képes a piacról azonnal pótolni, és az erőforrás biztosítóknak sincs megfelelő alternatív felhasználási lehetôségük. Ök a nagyobb díjazás érdekében végzik a specializációt, amivel nagyobb kockázatot is vállalnak. Itt mindkét fél érdekelt a további szoros együttműködésben.

A vállalatnak a specializált erőforrás-biztosítókkal szemben tanúsított magatartása alapvetően meghatározza, hogy milyen mértékben vannak az erőforrások a vállalat igényeihez igazítva (mennyire specializáltak). Ha a vállalat teljesíti elvárásaikat, akkor az megfelelő ösztönzést nyújt a további specializációra, amely mértéke alapvetően meghatározza a vállalat sikerét. A megfelelő motiváltság biztosítása érdekében a specializált erőforrás-biztosítókat a vállalat eredményességének függvényében kell díjazni. Így egyértelmű számukra, hogy díjazásuk szorosan kapcsolódik az általuk nyújtott teljesítményhez ${ }^{18}$. Ennek következtében a specializált erőforrást biztosítók is bizonyos mértékben reziduális követeléssel rendelkezővé válnak.

Viszont a menedzsment elvileg arra az álláspontra is helyezkedhet, hogy nem szentel kiemelt figyelmet az ilyen specializált erőforrást biztosítóknak, mivel nincsen az erőforrásoknak megfelelő alternatív felhasználása. Ebben az esetben azonban a specializált erőforrást biztosítóknak nincsen ösztönzése a vállalat igényeihez való optimális erőforrás-specializációra, ami a vállalat hatékonyságának jelentős csökkenését okozza.

Hatékonysági szempontból csak a vállalatspecifikus erőforrást biztosítókat kell érdekhordozónak tekinteni. Jól illeszkedik rájuk Kochan - Rubinstein (2000) megfogalmazása, akik szerint az igazi érdekhordozónak három jellemzővel kell rendelkeznie:

- az érdekhordozónak értékes erőforrást kell a vállalat rendelkezésére bocsátania,

- a rendelkezésre bocsátással a tulajdonos ezeket az erőforrásokat kockázatnak teszi ki, azaz vesztesé- 
get szenvedne, ha a vállalat megbukna, illetve kapcsolata a vállalattal megszakadna,

- az érdekhordozónak megvan a hatalma a vállalat működésének befolyásoláshoz.

A vevőket itt nem tekintem erőforrás-biztosítónak, mert a közgazdasági logika szerint ellentétes az érdekük a többi vállalati szereplővel (Windsor, 1998). Tehát az előbb meghatározott definíciót csak a kínálati oldal egyes szereplőire vonatkoztatom. Úgy tekintek a vállalatra, mint a kínálati oldal szereplőinek (az összes érdekhordozó + egyéb standard erőforrást biztosítók) szoros együttműködésére, team munkájára, ami eredményeképpen jön létre a vevőknek kínált termék és szolgáltatás. A vállalat teljesítményét pedig a vevők önérdeke határozza meg, azaz a vállalat működési hatékonysága és ez alapján az érdekhordozók díjazása a kereslet függvénye.

Az erőforrás-függőségen alapuló érdekhordozói szemléletmód azzal támasztható alá, hogy ma már nem olyan egyértelmû, mint száz évvel korábban, hogy mi is a részvénytársaság legfontosabb erőforrása (Kochan - Rubinstein, 2000). Számos esetben a menedzserek és az alkalmazottak speciális tudása és képessége válik a kompetitív előny alapjává és így a legkritikusabb erőforrássá (Drucker, 1980; Thurow, 1996; Arrow, 1996). Ebből már megérthető, hogy az érdekhordozói elmélet miért mutat nagyobb összhangot a vállalkozói vállalatokkal, a részvényesi elsőbbség megközelítés pedig miért illik jobban a nagyobb, kiforrottabb vállalatokra (Freeman et al, 2004). A vállalatoknak azonban nemcsak a vállalati alkalmazottak, hanem más vállalati szereplők (pl. egyes szállítók) speciális tudására és képességére is szükségük van. Így számos részvénytársaság esetén a részvénytőke csak egyike a vállalat kritikus erőforrásainak.

Az itt megfogalmazott érdekhordozói vállalatelmélet koncepciójának kialakításánál igen fontos feladat a vállalat alapvető céljának, azaz egy egydimenziós teljesítménymérő rúdnak a meghatározása, ami alapján a vállalat teljesítménye jól mérhetô és egyértelműen megítélhető. Ennek hiányában nem lehet hatékonyságra épülő elméletről beszélni. Ez pedig a hosszú távú nyereségesség lesz. De ennek ellenére a részvényeseket nem tekintem a részvénytársaság gazdasági értelemben vett tulajdonosainak vagy megbízóinak (Kárpáti, 2005). Nyilvános részvénytársaság esetén a részvényesek egyenrangúak a többi vállalati szereplővel. Nem a tulajdonjogukból kifolyólag kapják a díjazásukat, hanem a többi érdekhordozóhoz hason- lóan azért, mert támogatásuk szükséges a vállalat fennmaradásához (Freeman, 2001). Azonban fontos látni, hogy itt Freeman megközelítésétől eltérve a vállalati szereplőknek csak egy része rendelkezik érdekhordozói státusszal, tehát csak ezek lesznek reziduális követeléssel rendelkezőként azonosítva ${ }^{19}$.

A vállalatirányítás feladata a kitermelt érték megfelelő felosztása. Az érdekhordozók egymástól részben eltérő céljainak olyan mértékű teljesítését kell biztosítani, ami már megfelelően ösztönzi őket a vállalati célok elérésére. $\mathrm{Az}$ érdekhordozók elkötelezettsége nélkül ugyanis a részvénytársaság hatékony múködése nem biztosíthatớ. Másképp fogalmazva az alapvető probléma nem a megbízó-ügynök viszony hatékony kezelése, hanem az érdekhordozók teammunkájának hatékony megszervezése (Blair - Stout, 1999; Kochan - Rubinstein, 2000).

Hatékonyság szempontjából további hiányossága az érdekhordozói elméletnek, hogy az érdekek közötti egyensúlyozással kapcsolatban képtelen a menedzsment számára egy algoritmust kialakítani. Nem ad útmutatást, hogyan lehet ezt a megközelítést a mindennapokban alkalmazni (Phillips et al, 2003). Ezért előfordulhat olyan szituáció, ahol az érdekhordozói szemléletmódú vállalatirányításra történő áttérés következtében az érdekhordozók ugyan hatékonyabban végzik a tevékenységeiket, de a vállalat kevesebb profitot, azaz hatékonytalanabb múködést képes felmutatni. Ez pedig azért van, mert egyes érdekhordozók érdekét túlságosan figyelembe veszik került (díjazásuk túl magas). Ezért egy érdekhordozó érdekét maximum olyan mértékig lehet figyelembe venni, amíg az így felmerülő költséget még éppen meghaladja a biztosított erőforrás felhasználásából származó hasznosság. De a vállalat annál hatékonyabb, minél kevesebb díjazásért cserébe képes a szükséges mértékben specializált erőforrásait beszerezni.

Az érdekhordozók reziduális követeléssel rendelkező pozíciójának jelentősége ott látható, hogy ellentétben áll a részvényesi elsőbbséget leginkább alátámasztó vállalat, mint szerződések nexusa elméletek szemléletmódjával. Ezek ugyanis arra az előfeltevésre építenek, hogy a vállalati szereplők mindegyike kompetitív díjazásban részesül, ami az általuk végzett tevékenység piaci ára. Ez a díjazás nem kapcsolódik szorosan a vállalat tényleges teljesítményéhez, ezért fixnek tekinthető ${ }^{20}$. Azaz ők ezért az árért a piacról bármikor pótolhatók. Kizárólag a részvényesek rendelkeznek reziduális követeléssel, nekik jut a bevételek és a költségek közötti különbözet. 
A dolgozat lezárásaként érdemes még egyszer áttekinteni a legfontosabb gondolatokat. A korábbi bekezdésekben egy alternatív vállalatszemlélet kialakítására került sor, amely a vállalat erőforrás-függőségéből indul ki. Itt nemcsak a részvénytőke a kritikus erőforrás. A vállalat olyan erőforrásokat is igényel, amelyek - a vállalat igényeihez illeszkedő - specializációjának mértéke alapvetően meghatározzák működésének hatékonyságát, de a megfelelő mértékben specializált erőforrások a piacról automatikusan nem szerezhetők be. Jól látható, hogy a vállalat szempontjából ezek biztosítói is kritikus erőforrást birtokolnak. Megfelelő ösztönzésük a vállalat egyik legfontosabb feladata. Elkötelezetté kell őket tenni, hogy tevékenységüket a vállalat érdekével összhangban folyamatosan fejleszszék. Díjazásukat a vállalat eredményességének függvényében (pl. nyereségrészesedés, opció) kell meghatározni. Ez ugyanis megteremti a lehetőséget, hogy az erőforrás-biztosító az erőforrásának piaci áránál nagyobb díjazást realizálhasson. Tehát a menedzsment képes a specializált erőforrást biztosítók - érdekhordozók - vállalatban lévő érdekének (stake) növelésére. Sőt, ez az egyik legfontosabb feladata a minél magasabb szintű vállalati hatékonyság biztosítása érdekében. Az érdekhordozók egyéb, nem pénzügyi érdekeit is figyelembe lehet venni a döntéshozatal során. De a cél különböző érdekeik olyan mértékű figyelembevétele, ami már biztosítja a szükséges mértékben specializált erőforrásokat, és a vállalatnak a lehető legkevesebb költséggel jár. Ez az érdekhordozói vállalatszemlélet teljes mértékben a hatékonyság talaján áll, és megvan benne az a potenciál, hogy megfelelően figyelembe vegye a vállalatspecifikus tudás kritikus szerepét. Így egy olyan alternatív vállalatelméleti megközelítés irányába történt elmozdulás, ami a szerződéses vállalatelméleti megközelítésekkel szemben jobban illeszkedik a gyors változásokkal jellemezhető környezetben működő, erősen tudásintenzív részvénytársaságokra.

\section{Felhasznált irodalom}

Alchian, A. A. - Demsetz, H. (1972): Production, Information Costs, and Economic Organisation. The American Economic Review, 62. évf., 5. szám, 777-795.

Argandona (1998): The Stakeholder Theory and the Common Good. Journal of Business Ethics, 17. évf., 1093-1102.

Arrow, K. (1996): The Rational Foundations of Economic Behavior. New York, MacMillan

Barry, N. (2002): The Stakeholder Concept of Corporate Control Is Illogical and Impractical. The Independent Review, 6. évf., 4. szám, 541-554.

Blair, M. M. - Stout, L. A. (1999): A Team Production Theory of Corporate Law Journal of Corporation Law, 24. évf., 4. szám, 751-806.
Berle, A. A., Jr. (1931): Corporate Powers as Powers in Trust. Harvard Law Review, 44. évf., 1049-1074.

Berle, A. A., Jr. (1932): For Whom Corporate Managers Are Trustees. Harvard Law Review, 45. évf., 1365-1372.

Berle, A. A. - Means, G. C. (1932): The Modern Corporation and Private Property. Murray L. Weidenbaum és Mark Jensen új bevezetésével, New Brunswick, NJ: Transaction Publishers, (1991)

Berman, S. L. - Wicks, A. C. - Kotha, S. - Jones, T. M. (1999): Does Stakeholder Orientation Matter? The Relationship between Stakeholder Management Models and the Firm Financial Performance. Academy of Management Journal, 42. évf., 5. szám, 488-506.

Boatright, J. R. (1994): Fiduciary Duties and the ShareholderManagement Relation: or, What's so Special about Share-holders? Business Ethics Quarterly, 4. évf., 4. szám, 393-408.

Burton, B. K. - Dunn, C. P. (1996): Feminist Ethics as Moral Grounding for Stakeholder Theory. Business Ethics Quarterly, 6. évf., 2. szám, 133-148.

Calomiris, C. W. - Ramirez, C. D. (1996): Financing the American Corporation: The Changing Menu of Financial Relationships. In: The American Corporation Today, szerk: C. Kaysen, 128186, New York, Oxford University Press

Clarkson, M. (1994): A Risk Based Model of Stakeholder Theory. A tanulmány az érdekhordozói elméletrôl tartott második torontói konferencia keretében került előadásra, Toronto: Centre for Corporate Social Performance \& Ethics, University of Toronto

Coase, R. H. (1937): The Nature of the Firm. In: The Nature of the Firm: Origins, Evolution, and Development, szerk.: O. E. Williamson és S. G. Winter, 18-33, New York: Oxford University Press

Cook, J. - Deakin, S. (2000): Stakeholding. In: ESRC Centre for Business Research, Literature Survey on Factual, Empirical and Legal Issues, 1. fejezet, az anyagok a DTI Company Law Review számára készültek.

Dodd, E. M. Jr. (1932): For Whom Are Corporate Managers Trustees? Harvard Law Review, 45. évf., 7. szám, 1145-1163.

Donaldson, T. (1999): Making Stakeholder Theory Whole. Academy of Management Review, 24. évf., 2. szám, 237-241.

Donaldson, T. - Dunfee, T. W. (1999): Ties That Bind. Boston, Harvard Business School

Donaldson, T. - Preston, L. E. (1995): The Stakeholder Theory of the Corporation: Concepts, Evidence, and Implications. Academy of Management Review, 20. évf., 1. szám, 65-91.

Drucker, P. (1980): Managing in Turbulent Times. New York, Harper and Row

Evan, W. M. - Freeman, R. E. (1988): A Stakeholder Theory of the Modern Corporation: Kantian Capitalism. In: Ethical Theory and Business, szerk., T. L. Beauchamp és N. E. Bowie, 75-93, Englewood Cliffs, NJ, Prentice Hall

Evan, W. M. - Freeman, R. E. (1993): A Stakeholder Theory of the Modern Corporation: Kantian Capitalism. In: Ethical Theory and Business, szerk., T. L. Beauchamp és N. E. Bowie, 97-106, Englewood Cliffs, NJ, Prentice-Hall

Fama, E. F. (1980): Agency Problems and the Theory of the Firm. Journal of Political Economy, 88. évf., 2. szám, 288-307.

Fama, E. F. - Jensen, M. C. (1983): Separation of Ownership and Control. Journal of Law \& Economics, 26. évf, 2. szám, 301326.

Fama, E. F. - Jensen, M. C. (1983): Agency Problems and Residual Claims. Journal of Law \& Economics, 26. évf, 2. szám, 327-349. 
Freeman, R. E. (1984): Strategic Management: A Stakeholder Approach. Boston: Pitman

Freeman, R. E. (1994): The Politics of Stakeholder Theory: Some Future Directions. Business Ethics Quarterly, 4. évf., 4. szám, 409-421.

Freeman, R. E. (1999): Divergent Stakeholder Theory. Academy of Management Review, 24. évf., 2. Szám, 233-236.

Freeman, R. E. - Evan, W. M. (1990): Corporate Governance: A Stakeholder Interpretation. Journal of Behavioral Economics, 19. évf., 4. szám, 337-359.

Freeman, R. E. - Reed, D. L. (1983): Stockholders and Stakeholders: A New Perspective on Corporate Governance. California Management Review, 25. évf., 3. szám, 88-106.

Freeman, R. E. - Wicks, A. C. - Parmar, B. (2004): Stakeholder Theory and „The Corporate Objective Revisited”, Organization Science, 15. évf., 3. szám, 364-369.

Friedman, M. (1970): The Social Responsibility of Business Is to Increase Its Profits. New York Times Magazine, szeptember 1, In: Ethical Theory and Business, szerk.: Tom L. Beauchamp és Norman E. Bowie, Englewood Cliffs, N. J.: Prentice-Hall, (1993)

Frooman, J. (1999): Stakeholder Influence Strategies. Academy of Management Review, 24. évf., 2. Szám, 191-205.

Goodpaster, K. E. (1991): Business Ethics and Stakeholder Analysis. Business Ethics Quarterly, 1. évf., 1. szám, 53-73.

Harrison, J. S. - Freeman, R. E. (1999): Stakeholders, Social Responsibility, and Performance: Empirical Evidence and Theoretical Perspectives. Academy of Management Journal, 42. évf., 5. szám, 479-485.

Hasnas, J. (1998): The Normative Theories of Business Ethics: A Guide for the Perplexed. Business Ethics Quarterly, 8. évf., 1. szám, 19-42.

Hendry, J. (2001): Missing the Target: Normative Stakeholder Theory and the Corporate Governance Debate. Business Ethics Quarterly, 11. évf., 1. szám, 159-176.

Hill, C. W. L. - Jones, T. M. (1992): Stakeholder-Agency Theory. Journal of Management Studies, 29. évf., 2. szám, 131-154.

Jennings, M. M. (1999): Stakeholder Theory: Letting Anyone Who's Interested Run the Businesss - No Investment Required. Conference Paper, Center for Business Ethics, Cameron School of Business University of St. Thomas

Jensen, M. - Meckling, W. (1976): Theory of the Firm: Managerial Behaviour, Agency Costs and Ownership Structure. Journal of Financial Economics, 3. évf., 304-360. http://ssrn.com/abstract $=94043$

Jensen, M. C. (2001): Value Maximisation, Stakeholder Theory, and the Corporate Objective Function. European Financial Management, 7. évf., 3. szám, 297-317.

Jones, T. M. (1995): Instrumental Stakeholder Theory: A Synthesis of Ethics and Economics. Academy of Management Review, 20. évf., 2. szám, 404-441.

Jones, T. M-Wicks, A. C. (1999): Convergent Stakeholder Theory. Academy of Management Review, 24. évf., 2. szám, 206-221.

Kárpáti T. (2005): A részvénytársaság, mint társadalmi intézmény a gazdaság erôforrás-alapú nézőpontjából. Külgazdaság, megjelenés alatt.

Kochan, T. A. - Rubinstein S. (2000): Toward a Stakeholder Theory of the Firm: The Saturn Partnership. Organization Science, 11. évf., 4. szám, 367-386.

Lazonick, W. - O'Sullivan, M. (2000): Maximizing Shareholder Value: A New Ideology for Corporate Governance. Economy \& Society, 29. évf., 1. szám, 13-35.

Learmount, S. (2002): Theorizing Corporate Governance: New Organizational Alternatives. ESRC Centre for Business Research, University of Cambridge, Working Paper 237.
Letza, S. - Sun, X. (2002): Corporate Governance: Paradigms, Dilemmas and Beyond. Leeds Law School, Leeds Metropolitan University, 2. évf., 1. szám. http://www.puereview.ae.poznan.pl/2002v2n1/03-letza.pdf

Mayer, F. (1997): Corporate Governance, Competition and Performanc., In: Enterprise and Community: New Directions in Corporate Governance, szerk.: Deakin, S. és Hughes, A., Blackwell Publishers: Oxford

Metcalfe, C. E. (1998): The Stakeholder Corporation. Business Ethics: A European Review, 7. évf., 1. szám, 30-36.

Millon, D. (1990): Theories of the Corporation. Duke Law Journal, 201-262.

Mitchell, R. K. - Agle, B. R. - Wood, D. J. (1997): Toward a Theory of Stakeholder Identification and Salience: Defining the Principle of Who and What Really Counts. Academy of Management Review, 22. évf., 4. szám, 853-886.

Moore, G. (1999): Tinged Shareholder Theory: or What's so Special about Stakeholders? Business Ethics: A European Review, 8. évf., 2. szám, 117-127.

Orts, E. C. (1992): Beyond Shareholders: Interpreting Corporate Constituency Statutes. George Washington Law Review, 61. évf., 14-135.

Paterson, J. (2001): Corporate Governance, the Limits of Rationality and Proceduralisation. ESRC Centre for Business Research, University of Cambridge, Working Paper 198.

Phillips, R. (2003): Stakeholder Legitimacy. Business Ethics Quarterly, 13. évf., 1. szám, 25-41

Phillips, R. - Freeman R. E. - Wicks, A. C. (2003): What Stakeholder Theory is not. Business Ethics Quarterly, 13. évf., 4. szám, 479-502.

Prahalad, C. K. (1994): Corporate Governance or Corporate Value Added?: Rethinking the Primacy of Shareholder Value. Journal of Applied Corporate Finance, 6. évf., 4. szám, 40-50.

Roe, M. J. (1994): Strong Managers, Weak Owners: The Political Roots of American Corporate Finance. Princeton, NJ, Princeton University Press.

Smith, G. D. - Dyer, D. (1996): The Rise and Transformation of the American Corporation. In: The Changing American Corporation, szerk., C. Kaysen, 28-73, New York, Oxford

Sundaram, A. K. - Inkpen, A. C. (2004): The Corporate Objective Revisited. Organization Science, 15. évf., 3. szám, 350-363.

Sternberg, E. (1997): The Defects of Stakeholder Theory. Corporate Governance, 5. évf., 1. szám, 3-10.

Strenberg, E. (1999): The Stakeholder Concept: A Mistaken Doctrine. Foundation for Business Responsibilities, Issue Paper 4. szám, http://ssrn.com/abstract=263144

Stoney, C. - Winstanley, D. (2001): Stakeholding: Confusion or Utopia? Mapping the Conceptual Terrain. Journal of Management Studies, 38. évf., 5. szám. 603-626.

Thurow, L. C. (1996): The Future of Capitalism. New York, W. Morrow \& Co.

Turnbull, S. (1997): Corporate Governance: Its Scope, Concerns \& Theories. Corporate Governance: An International Review, Blackwood, Oxford, 5. évf., 4. szám, 180-205.

Useem, M. (1996): Investor Capitalism. New York, Basic Books

Wallman, S. M. H. (1999): Understanding the Purpose of a Corporation: An Introduction. J. Corp. L., 24. évf., 4. szám, 807-818.

Weiner, J. L. (1964): The Berle-Dodd Dialogue on the Concept of the Corporation. Columbia Law Review, 64. évf., 1458-1467.

Wicks, A. C. - Gilbert, D. R. - Freeman, R. E. (1994): A Feminist Reinterpretation of the Stakeholder Concept. Business Ethics Quarterly, 4. évf., 4. szám, 475-497.

Williamson, O. E. (1975): Markets and Hierarchies. New York, Free Press

Williamson, O. E. (1985): The Economic Institutions of Capitalism. New York, Free Press

Windsor, D. (1998): The Definition of Stakeholder Status. Az IABS (International Association for Business and Society) éves konferenciáján került előadásra, Kona-Kailuna, Hawaii 


\section{Lábjegyzetek}

${ }^{1} \mathrm{Az}$ angol stakeholder szót érintettnek és érdekhordozónak is szokták fordítani.

2 Ide értem a vállalat, mint szerződések nexusa megközelítést, a tranzakciós költségek elméletét és a nem teljes szerződések elméletét.

3 Ezekrôl jó áttekintést ad Turnbull (1997), Letza-Sun (2002) és Learmount (2002).

4 A 90-es évek második felében az Alfred P. Sloan Alapítvány finanszírozásával egy olyan kutatás zajlott („,The Corporation and Its Stakeholders”), amely keretében a részvénytársaság természetét és irányítását érdekhordozói szempontból vizsgálták. A projekt weboldala: http://www.rotman.utoronto.ca/ stake/, 2004. 12. 03.

5 A menedzsmentnek a vevőkkel szembeni kötelezettsége a munkavállalókkal szembeni kötelezettségéhez hasonló.

6 Ezzel egy idôben a pénzügyi piacokon bekövetkezô változások lehetővé tették a vállalatfelvásárlások hatékony piacának létrejöttét, amely eredménye a nyolcvanas évekbeni ellenséges felvásárlási hullám lett.

7 Hivatkozik rá: Kochan - Rubinstein (2000).

8 A túl kizáró jelzô arra vonatkozott, hogy az SRI csak a részvényesekre, a munkavállalókra, a vevőkre, a szállítókra, a hitelezôkre és a közösségre (society) gondolt. A túl általános jelző pedig arra, hogy például nem a vevőkkel kell foglalkozni, hanem speciális vevôi szegmensekkel. Tehát nem általános kategóriákban, hanem speciális csoportokban kell gondolkodni.

${ }^{9}$ Egyrészt a menedzsment és a részvényesek nincsenek egymással szerződéses viszonyban, másrészt ettől eltekintve sem áll fenn megbízó-ügynök viszony kettejük között (Boatright, 1994).

10 Idézi: Cook - Deakin (2000)

11 Ez csak abban a speciális esetben történhet meg, ha a dimenziók egymás monoton transzformációi.

12 Ez ugyanazokból a költségtípusokból áll, mint az ügynökköltség, tehát az ösztönzési, a monitoring és a kikényszerítési mechanizmusok költségeiből valamint a megmaradó reziduális veszteségből. Az utolsót ebben a megközelítésben reziduális hasznossági veszteségnek hívják.

13 Erre Freeman - Evan (1990) a következỏ példát hozta. Ha két ember között fair módon akarunk elosztani egy süteményt, akkor ez úgy érhető el, ha az egyik fél vágja két részre a süteményt, de a másik fél választja ki a saját részét.

14 Ez Freeman - Reed (1983) szúkebb érdekhordozói definíciójára vonatozik.

15 Itt a szerzôdést a hagyományos felfogáshoz képest szélesebben kell értelmezni.

16 Ez a költség itt mindig fel fog merülni, ugyanis a felek a másik fél lehetséges opportunizmusának csökkentése érdekében költséges mechanizmusokat alakítanak ki, valamint az opportunizmus következtében is merülnek fel költségek.

17 Idézi: Cook - Deakin (2000).

18 Habár a vállalat eredményességét és így a specializált erőforrást biztosítók díjazásának nagyságát vállalaton kívüli tényezốk is befolyásolják, ennek ellenére nyilvánvaló, hogy a vállalat eredményében való részesedésük mértéke az általuk biztosított erốforrás fontossága alapján határozódik meg.

19 Ha egy szállító tömegterméket értékesít a vállalatnak, akkor ő nem tekinthető érdekhordozónak, és így érdeke csak olyan mértékben lesz figyelembe véve, mint ahogy azt a részvényesi elsőbbség megközelítés esetén tennék.

20 Alchian - Demsetz (1972) és Jensen - Meckling (1976) szerzőpárosok fixnek feltételezik a vállalati szereplők haszonáldozati költségét, nem foglalkoznak részletesen ezzel a kérdéskörrel. Fama (1980) és Fama - Jensen (1983) érvelése is egy kategóriába sorolható az előbb említett szerzőkével. Habár náluk az idôszak elején még nem biztos, hogy ismert a menedzser fizetésének konkrét nagysága, de kötve van az általa nyújtott teljesítmény alapján a menedzserek piacán fennálló díjazáshoz. Díjazásuk így fix abban az értelemben, hogy a felmutatott teljesítménynek megfelelő piaci árral egyenlổ függetlenül attól, hogy a vállalat abszolút összegben mekkora profitot realizál. Tehát a jövedelmük ingadozása elsôsorban nem a vállalat működésének eredményességétől, hanem a saját teljesítmény piaci árától függ.

\title{
EMLÉKEZTETŐ!
}

\author{
Ne felejtse el megújitani \\ elöfizetését 2006-ra
}

